$12-21-2020$

\title{
Arts \& Literature: The Grey Zone
}

Sabah Carrim

Texas State University

Follow this and additional works at: https://digitalcommons.usf.edu/gsp

\section{Recommended Citation}

Carrim, Sabah (2020) "Arts \& Literature: The Grey Zone," Genocide Studies and Prevention: An International Journal: Vol. 14: Iss. 3: 3-10.

DOI:

https://doi.org/10.5038/1911-9933.14.3.1806

Available at: https://digitalcommons.usf.edu/gsp/vol14/iss3/4

This Arts \& Literature is brought to you for free and open access by the Open Access Journals at Digital Commons @ University of South Florida. It has been accepted for inclusion in Genocide Studies and Prevention: An International Journal by an authorized editor of Digital Commons @ University of South Florida. For more information, please contact digitalcommons@usf.edu. 
Arts \& Literature:

The Grey Zone

Sabah Carrim

Texas State University

San Marcos, Texas, USA

\title{
About the Art Work
}

This essay is the result of a combination of interviews conducted with Rithy Panh, Alexander Hinton, Peg LeVine, and Craig Etcheson by the author, as well as the field notes she collected while attending the IAGS conference in 2019 for which she was awarded a conference scholarship by the same organisation.

The author would also like to acknowledge Lukas Meissel for his valuable comments on the piece, especially in the formulation of Ori, a composite character.

The narrative takes place in two iconic tourist and memorial sites in Phnom Penh: The Killing Fields (aka Choeung Ek) and Tuol Sleng Genocide Museum (aka S21).

\begin{abstract}
About the Author
Sabah Carrim has a PhD in Genocide Studies and Prevention with a focus on the Khmer Rouge era. She has authored two novels and a few short stories that have been shortlisted in international competitions.
\end{abstract}

She is currently enrolled in a MFA in Creative Writing in Texas State University where she has been awarded the W. Morgan and Lou Claire Rose Scholarship and the Arch and Stella Rowan Foundation Scholarship. 


\section{The Grey Zone}

I'm on a bench, at the fourth checkpoint. Most of us have headsets clipped on, often awkwardly, in our Procrustean world with one-size trying to fit-all. We are listening to the story of a genocide. The Khmer voice of a man on the audio recorder is powerful, all the more since he intimated that he's a survivor. We are tourists, foreigners, a vulnerability that's hardly spoken of. Gullible. It's probably the pathos in the man's voice.

A fly sits on the back of my palm. My immediate thought is to situate it within the ecosystem of where I am, here at the Killing Fields in Phnom Penh. I explain what I mean, telling my travel companion Ori, how I've imagined what the fly must have been feeding on, although it's not true. It would have been true forty years ago when dead, rotting flesh of bodies lay here. But I like imagining, toying with Time, toying with thoughts, feeling new feelings. Ori is here for the first time, me the twelfth. My sole concern he thinks, is bacteria. Never mind. I have come here obsessively, compulsively, thirsting details, thirsting nuances, desiring more. It could have been done in one session, but I've opted for this shabby method. The most profound thoughts I've learned, are generated in moments of passivity and indolence.

Ori recommends mosquito repellant, or the citronella oil I always carry in my handbag. 'No,' I say, somewhat peevishly, 'that's not what I meant.' Can we stop being fastidious, we the travellers of the world? Can we get over our fixations with sanitisers and antibacterial wipes and door handles and taps and bannisters and people sneezing in airports?

This is a place of overreactions.

Thank god I'm old enough to exercise restraint in voicing my thoughts. Thank god my thoughts are not audible.

I think of the irony of our lives, identifying and avoiding old traps, stumbling and falling into new ones, never knowing. And carrying on, stubborn, fastidious.

'No,' I repeat, still looking down at the fly. 'Let it be.' This fly is part of the ecosystem of this tourist site, once an orchard. Where the gentle concaves you see in the ground, the Khmer voice says, are erstwhile mass graves from another era.

The atmosphere is not any bit different from my home in Mauritius, at Sir Guy Forget Street, with the chirping of birds, the crows of a rooster, the quiet air of a weekday, a Sunday, a sunny day-because even sunniness has a sound of its own. Though the grass here in Phnom Penh is different. It's smooth, motherly, like a blanket, vividly green, unlike the sharply defined blades of dark green back home. There it's young, zealous, impetuous, too keen on knowing, growing, compared to this, which has known, grown, and understood, and still retained softness and permeability. And while thinking about this, I become conscious of how my recent knowledge of the predominance of Buddhist stoicism in Khmer culture has placed a veil before my eyes, and changed the way I see things, the way I describe them. We keep speaking of removing layers of prejudice from our thinking which we somehow manage to do by exposing ourselves to books and people, and scantly of the ones we add, very subtly while we're at that. 
If I went on, I could find more differences in my entourage. The rest of the vegetation for example, but never mind that. I don't know the names, and I envy those who do, because every new name signifies a new identity. Heightened awareness. And what could be more empowering than the ability to differentiate things in a mass of confused mess?

I can't help finding it uncanny that right now in the Killing Fields if I closed my eyes, I could very well be in Mauritius. Because at S-21, now the Genocide Museum of Phnom Penh, a former primary school converted into a security prison between 1975-1979, where 14,000 inmates were tortured, it's entirely different. There, there are no birds, no chirping, just silence, not even a solemn one, but calm indifference. One immune to violence, death, the past, the pain. One that carries on, despite everything, and may I say, even lightly, cheerfully, mocking us.

Craig Etcheson, a Cambodia expert, told me that an NGO or a parastatal body (I'm not sure which) had wanted to plant flowers at S-21. How horrible, he said, what a lack of respect. Yes, I replied, how horrible, and shook my head. With hindsight, it was sheer complaisance- $\mathrm{I}^{\prime}$ ve read that we tend to do that in conversations. After he left, I asked myself, what if they did? The flowers would have made the air light, given it cheer, mocking us, our seriousness. And suppose a bird had left its droppings of the seeds it had eaten, and flowers started growing by an act of 'nature,' would it make it less condemnable?

By planting flowers, the planners, the gardeners would only be capturing the same spirit.

And then life seems to have moved on in many ways. At S-21, they've already tidied up so much. I think of what's left of the barbed wires, once distinctive barriers to liberty, escape, now barely noticeable, where the license to enter and exit no longer hinges upon questions of life and death. I think of the general cleanliness of the premises, the constant repairs and renovations that conceal more and more of the horrors of the past. I think of the board with the clearly defined Do's and Don'ts that has been rewritten neatly to mark a time in the past when prisoners were constrained by them. I think of the many times the grass has been mowed, weeded, manicured. How sterile it smells there. It mustn't have been like that forty years ago, in that state of advanced panopticism, where classrooms once classifying children, were further divided to pen prisoners to be disciplined and punished, they too innocent, before and after they had been brought out to be photographed, their nails tweezed out, their heads drowned in tubs of water, pulled and dragged like cattle, until they concocted confessions, denouncing friends and relatives, proving Schopenhauer and Nietzsche right that everyone's really selfish, and where the totality of their pain and suffering made those premises smell like an animal farm. Now, forty years later, after the blood stains on the wall have faded, planting seeds, growing flowers, adding colour couldn't possibly make a difference.

I'm not saying Craig Etcheson is wrong. I just don't see the point in taking sides. There seem to be arguments to support every damn thing these days. The chaos of postmodernism.

I wish like Rithy Panh, the Cambodian filmmaker, who needed to know, to understand, to energise intuition to produce documentaries, that I could also be 
here at the Killing Fields in the evenings, at night, when there is no gullibility, when there is a different kind of silence.

You must have heard the crickets at that time, didn't you Mr Panh? Tell me. Because I want to feel what the prisoners felt when they were brought here in those trucks, blindfolded, on that winding, unpaved, and pebbly road over eight kilometres, from their prison cells in S-21, and hacked to death with axes and sharpened bamboo sticks in pits dug at the Killing Fields. I read that bullets were too few and precious to be wasted on them. Is it true? I want to know Mr Panh, whether you looked up at the sky on those evenings, and saw the same number of stars I see in Mauritius, or whether your sky there was just blank, like in most of the polluted cities of Southeast Asia. Tell me, Mr Panh, did you wait until the noises of the night had died down? Did you wait to feel what it must have been like for a prisoner to smell the stench of dead and dying bodies, progressing through pallor mortis, algor mortis, rigor mortis, livor mortis, and finally putrefaction? Or still, did you try to feel how it must have felt knowing that one would die the following morning? And then, as I imagine many to have experienced, did you wait to feel your heart bursting with hope that it wouldn't happen? I want to know, Mr Panh, because I am an academic, a researcher, and I have kept a comfortable distance from feeling too much. And now that I am working on a conclusion to my doctoral thesis, I realise there should be none. To conclude is to abbreviate the thought process, to conclude is to be tired of thinking. To conclude would amount to a simplification, to evidence of my gullibility, an affront to the memory of the skulls and bone fragments I see segregated, labelled, and caged in glass boxes, and the chankiri tree where babies and young infants were smashed to death, where music was played to drown the voices of those crying, struggling, bleeding.

'If you claim that you don't know the names of trees,' says Ori, 'how did you know it was the chankiri tree?'

'It's in books on the atrocities of the Khmer Rouge regime.'

Smiling isn't allowed here at the Killing Fields. An unspoken rule understandably. But I catch myself doing it when Ori takes a picture. I am seated on a bench (a different one) with thick roots of a tree whose name I don't know, framing me on three sides. I look around self-consciously. This feels wrong. It wasn't like that the first time-I was more serious, more morose. The tourists, those first-timers, are probably appalled by my reaction. The guilt. I feel it so easily when I am here. But then, I feel everything so easily over here. This is a sacred place, a place that makes you anxious, uncomfortable. Not because of the rules, no, but the shadows around them. I'm never sure what's allowed and what's not. Can I smile, laugh, answer my mobile?

Over here, there can be no comfort in experiencing one emotion at a time. Every emotion is like a runny egg in a tray. At times, you feel guilty for not feeling, like I felt just now. At other times, for feeling too much-especially when you wonder whether you've been manipulated into experiencing this or that at different checkpoints. Look at the tourists, stopping where they are told under a covered shelter erected for the purpose, ruminating over what the Khmer voice tells them 
to ruminate. It's not that I doubt the story-I despise the manipulation. Poststructuralism.

'You're such a rebel. I don't know anyone who'd think like you,' says Ori, after I share my thoughts with him.

'If I exist, there must be others who feel the same way,' I reply. 'They're just not saying it.'

Long ago, when I was a teenager, I remember how often I was haunted by bouts of confusion. My thoughts were jumbled up. It made me restless, moody. I kept wondering if other people felt the same way. I recall my journal entries: 'Something's bothering me, I don't know what it is, I need to take some time off to think about it.' And all efforts were in vain. Today it's different. My thoughts are clear. I know when and why I'm depressed, confused, happy, angry, sad. I empowered myself by learning how to express my innermost thoughts. A language schoolbooks don't teach. No longer do I feel estranged from myself-Only from everyone.

As I said earlier, the problem is not the rules but the shadows around them. That grey area, the penumbra. The space that gives us leeway to exercise discretion, to engage creativity, to feel empowered, to feel we exist. The will to power. Sipo Matador. And Duch, head of S-21, went all the way. When Duch was given orders to kill, no one told him how to do it. And later in court during his trial, he used it in his defense. He said he merely followed the rules, obeyed the orders, that he was innocent-a puppet. He didn't tell everyone however, how vaguely these commands were phrased so that he allowed himself to devise intricate ways to carry them out, to mete out the torture, to issue orders to kill.

A book was found on the premises of S-21: La Torture by Alec Mellor. It was Duch's.

Some say Duch didn't know enough about Communist ideology, others say Duch knew more than Pol Pot, Nuon Chea, those in the maquis. Some say Duch was cultured, others that he was a simpleton. Some say Duch spoke like a wise man, others that he was a glib talker. Some say Duch knew the difference between the works of Michaelangelo and Picasso, others say yes, but only superficially. Some say Duch was so classy he drank cointreau neat with a slice of lemon. Duch was intelligent, Duch was effeminate. Duch liked to laugh, Duch never laughed. Duch was a monster, Duch was just a man. Duch was manipulative, Duch was only pretending. Duch was a liar. Duch had a sharp memory. Duch was a leader. Duch was a follower, a lickspittle, constantly in need of someone to hero-worship, like Son Sen, like Christ. Duch saw himself in the figure of St Paul. Duch was charismatic, a teacher who led, who proselytised, who helped cull a typhoid outbreak. Duch was gentle, a romantic_-remember how he loved Kim? Duch was sick, a sadist—remember how he tortured Bophana?

Duch.

What if Duch was all of that at different moments, like us? Aren't we dumb and smart, docile and resilient, deep and superficial? The problem: our bias for fixity of character. It is said that the ingenuity of Stendhal's Le Rouge et Le Noir was that it was among the first novels to present a character (Julien Sorel) who possessed a 
diversity of traits that stood in opposition to one another-a practice that outraged critics of those times, who accused such authors of slander against the human race.

Yes, it's not the rules, but the shadows that cause confusion, that introduce complexity in the matter. A side thought: I've always wondered about that compulsive desire-no, that need in me to flout rules. I keep thinking I'd make a bad employee. I like coasting along borders, exploring them, feeling their limits. A certain languor invades me after one or two instances of obeying, complying. It's tiring to keep doing it well, I tell myelf, because obedience is hardly noticed, hardly lauded. Perhaps I am under the constant threat of (Batailleian) death and disappearance, and breaking laws reminds me that I am here. Perhaps I suffer from the perpetual need to feel I exist.

I've thought about it for a long time: It's not getting caught that gives me a thrill. It's deciding what to do with the penumbra.

I've just landed in Phnom Penh for the first time and hired a tuk tuk from the airport. (This is a moment that took place five years ago that I am now recollecting.) Halfway there, the driver passes me a laminated sheet of paper. He proposes to drop me at the hotel so I can check in and then hire him for the rest of the day. 'Twelve dollars,' he says. I see four faded pictures of tourist sites on the paper with names printed underneath. The options are Choeung Ek (a.k.a The Killings Fields), the Genocide Museum of Phnom Penh (a.k.a S-21 or Tuol Sleng), the Wat Phnom, and the Royal Palace. Like on a menu. 'Let's start with the first two,' I say.

Every other visit to Phnom Penh began exactly like this.

We've just arrived at S-21. I'm here for the sixteenth time, Ori the first. I've stopped going into the classrooms. Except for the first one on the left, in Building A, right after you enter. (I was about to say 'It's my favourite' but one can't-shouldn't say that.) In it, you see a picture on the wall. It's what the jail cell looked like when it was photographed after the Khmer Rouge regime was defeated by the Vietnamese forces in 1979. In the black and white picture, a half-naked man lies in a metal bed frame, dead, his body discoloured, bloated monstrously-like the drawing by the narrator of The Little Prince, of the boa constrictor digesting the elephant. (Am I allowed to think this? Maybe you can think it, but you should not voice it.) There are also iron shackles, and rod-shaped instruments of torture. Not far off lies an ammunition can, a standard feature in all jail cells, once used by prisoners to relieve themselves. I've often wished other cells in that row had similar gruesome stories to recount. Each with a story of its own, unique for the details, for what it implied about the modus operandi of the Khmer Rouge regime. Strategically, it would have made such an impression-as the pieces of bone fragments and teeth do, left like that, jutting out of the ground along the path we are made to tread in the Killing Fields. Or those eight thousand skulls, piled on top of one another, staring at you through glass cages in the Memorial Stupa at the Killing Fields, drowning you in Repetition, through Homogeneity, weighing you down by the purport and meaning of the term 'genocide.' 
It is said that the man who was assigned to re-organise S-21 into a museum, into a tourist site, followed the structure and technique he had used before in a site also converted into a museum to exhibit the atrocities of the Second World War.

Ori walks away on his own to explore. I head towards one of the benches, sheltered by a few trees, where one gets the view of fourteen white raised tombs of the bodies found in Building A, back in 1979. I take a seat, cross my legs, rest an arm along the back rest. Then I notice a signboard that says one should sit respectfully while here. I'm suddenly uncomfortable.

I've been thinking that I also have a problem with a different permutation of rules: those we call 'generalisations.' In the manner they impose themselves on you, on how destructive they are, refusing to yield to exceptions. How they're presented to you as all-encompassing dicta and truth propositions. How they become excuses for unfairly imposed sanctions and last-minute accusations. Yes, rules and generalisations are often immune to being called into question.

Writing a thesis is a formidable exercise, no doubt. If you've done enough research, most of your propositions or statements of opinion should tempt you into adding a digression that starts with 'But', 'However', 'Nevertheless'. (And possibly another series of 'But,' 'However,' 'Nevertheless' to that.) What a challenge it is to sustain the effort over four hundred pages. But there are footnotes, 'cf.,' so why not?

Now imagine in real life: We want to get the job done quickly. That's why we are drawn to generalisations: thinking is tiresome. Introducing exceptions at every bend: painful. We seem to want to avoid complexity. That's why no one allowed Hannah Arendt to say that a mass killer could have a plainer personality than they'd imagined. That's why it took so long for people to understand Primo Levi's quixotic notion of the victim-perpetrator. That's why no one wanted Peg LeVine to tell the court that not all marriages during the Khmer Rouge era were forced. That's why no one wanted Alex Hinton to speak about how justice had been meted out in other ways than we thought possible-other than through punishment, retribution, a court of law. That justice in Cambodia, in the aftermath of the Khmer Rouge era, was delivered just as well through silence. Through the burning of incense sticks. Through prayers. Over coffee in an informal chat between perpetrator and victim.

Ori walks towards me. 'One of the survivors of S-21 over there is selling his book. You can even have a chat with him,' he says.

‘Oh. Bou Meng,' I reply.

‘Why don't you join me?'

'No...I don't feel comfortable in that space. I've watched him many times, I wonder if he recognises me by now. I just feel... I don't know...a sense of discomfort when I think he's been doing this all his life. The tourists. The book sales. Repeating the story of what he endured ad nauseam ad infinitum. He must be tired, case-hardened, I know it's money, his livelihood, but I still feel I'd be bothering him.' 
'Maybe you've been here too many times,' says Ori. 'You're probably numb to all this. To him.' Ori is silent for a while. 'Or, maybe you feel too much.' Then he strides away in the direction of Bou Meng's table.

I mull over what he just said. Do I feel too much? If so, why? Which hormone, which neurotransmitter could account for it? I smile at myself, I sneer at my thoughts, my so-called feelings. Posthumanism.

Ori is back after a few minutes.

'That was strange,' he says. 'I bought the book, he signed it, and I didn't know taking a picture was also part of the deal. Bou Meng pulled me to his side just like that. I wasn't sure whether I was supposed to smile, like you know... when you take pictures...normal pictures.'

We say nothing, and move towards the exit.

Ori and I are on the verge of leaving the precincts of S-21.

'You didn't tell me about your interview yesterday for your PhD, the one with Alex Hinton,' says Ori.

'It was great, except for the clanking noises in the restaurant where we had the interview. I have no idea what they were up to. Drove me crazy. Couldn't concentrate.'

'Yes, your misophonia.'

'I mentioned it to Alex Hinton. Miso: hatred, phonia: noise. He asked what sort of reaction I have when I hear repetitive noises, slurping, and all that.'

'Ha ha. What did you say?'

'The truth. That it evokes such anger in me that it makes me want to...'

I suddenly realise where I am. In the grey zone between entering and exiting S-21. In a space that evokes anxiety about what's right and what's wrong. Instinctively I lower my tone:

'....kill someone.'

The guilt. 